BOJAN BEŠKOVNIK, Ph.D.

E-mail: bojan.beskovnik@intereuropa.si

Intereuropa, Global Logistics Service

Vojkovo nabrežje 32, SI-6000 Koper, Slovenia

ELEN TWRDY, Ph.D.

E-mail: elen.twrdy@fpp.uni-lj.si

University of Ljubljana,

Faculty of Maritime Studies and Transport

Pot pomorščakov 4, SI-6320 Portorož, Slovenia
Transport Logistics

Preliminary Communication

Accepted: Jan. 18, 2010

Approved: Mar. 8, 2011

\title{
AGILE PORT AND INTERMODAL TRANSPORT OPERATIONS MODEL TO SECURE LEAN SUPPLY CHAINS CONCEPT
}

\begin{abstract}
This article presents a strategic view of industry's expectations from the lean supply chains concept in relation to the container shipping industry. The global market is putting the shipping industry under strong pressure as new trends in logistics seek new opportunities to cut unnecessary costs and players in the supply chain management and in the intermodal transport. For this reason we performed a research on how the intermodal transport can secure efficient transport operations. The emphasis is mainly on setting up the agile port and intermodal transport model, in which all necessary subjects should be involved in a unique supply chain. Thus we analyzed port operators, shipping lines and inland transport operators and the way they eliminate waste processes in their everyday operation procedure. Considering all important dynamic facts in the container and shipping industry and our analyses of the intermodal service through the port of Koper we propose the agile port and inland operations model suitable to improve intermodal service and to secure lean supply chains for containerized cargo. Consequently, we came to the conclusion that some traditional subjects in the traditional supply chain are not needed; while others, like customs authorities and inspection companies should be involved adequately to secure efficient organization of agile services in the ports, on the borders between different countries and at final destinations.
\end{abstract}

\section{KEY WORDS}

lean supply chains, agile intermodal operations, shipping lines, port operators, inland transport operators

\section{INTRODUCTION}

Nowadays, more and more enterprises require ontime transnational services from logistics companies. This pressure is becoming even greater due to the development of global economy and trade, especially now in the era of global financial and economic crisis. Logistics has been called the last frontier which can, even at the present time, if improved, represent companies' primary source for making new profits and maintaining competitive advantages [1]. For this reason the entire logistics sector is entering a new era of building modern logistics, where lean and agile supply chains concepts play a crucial role. Lean supply chains employ continuous improvement processes which focus on the elimination of waste or non-value stops across the chain. An agile supply chain tries to achieve faster delivery and lead time flexibility. It deploys new technologies and methods, utilizes information systems/technologies and data interchange facilities, integrates the whole business process, enhances innovations all over the chain, and forms virtual companies and production based on customer-designed orders [2].

Nowadays, logistics should cut down on all waste operations and extra costs on door-to-door transportation, where the shipping industry must add its important part. Consequently, logistics in maritime container terminals and operations management problems have been deeply analysed and discussed in different papers and analyses by Steenken et al., Vis and de Koster, Notteboom et al. and others [3] [4] [5]. Paixao and Marlow propose that ports must adopt a completely new logistic approach and agility to cope with new trends on the market [6]. Shipping lines are in search of different possibilities to reduce their costs and transit time, and to speed up information exchange in order to offer lean supply chains for containerized cargo. They intend to act as global logistics providers, therefore putting pressure on other players in the traditional supply chain. Ports are important subjects in this new approach. According to an elaboration done by Van Klink and Van den Berg and McCalla ports can generate cost effective intermodal transport, especially with the use of rail, thus enlarging their hinterland and importantly stimulating intermodal transport $[7,8]$. Shipping lines are focused on these logistic possibilities, especially with direct manipulations between berths and rail wagons. 
Industry's expectations of cost and time savings dictate the establishment and use of lean logistics concepts. Lean logistics needs a reliable ocean service, an agile port service and inland transportation, supported by in-time documentation procedures and information. Reducing the number of logistics subjects in supply chains can speed up cargo flow, reduce cost elements and facilitate information flow. The shipping industry is therefore in a phase of dynamic and important changes. Consequently, the previously mentioned situation poses special importance to the developing agile port and inland transport models, where shipping lines may play a crucial role.

The role of logistics players in modern supply chains in connection to port performance and intermodal transport chains is the matter which has not been deeply analysed so far. Some researches have been done by Noteboom and Rodrigue, in which they analyse the port's function in connection with hinterland connections and inland intermodal terminals, and their function in supply chains [5, 9]. New trends indubitably dictate the necessity of such researches, in order to stimulate the development of new operational methods and logistics models.

\section{LEAN SUPPLY CHAINS CONCEPT EXPECTATIONS}

\subsection{Customers' expectations and needs}

According to different researches about customers' expectations in the supply chains, their needs and expectations evolved during the last few decades. One of the initial researches made by Forster in 1978 showed that from the shipper's point of view the service frequency, closeness to the port and facilities are the most important factors in choosing a transport route and port service. His study determined the priority of the service quality over the costs of the port service [10]. His second research in 1979 gave completely different results. Service costs and port charges were the most important factors when choosing the transport route and port.

These were the first studies of port service attractiveness over port costs and until today, different studies showed different results. For instance, the research done by $\mathrm{Ng}$ showed that users choosing between different Northern-European container ports were mostly influenced by efficiency and service quality, rather than by lower costs [11]. This can be extended also to inland transportation services from ports to final destinations.

Consequently, it can be emphasized that it is hard to predict customer's or shipper's expectations whether they are focused on service costs or service quality. In both cases they need a service without waste in the entire door-to-door transport route. Expectations of cost and time savings dictate the establishment and use of lean logistics concepts.

\subsection{Lean logistics}

"Lean" means a reduction of wastes and it has become an absolute requirement in today's logistics world. A lean supply chain shows how an optimal supply chain should operate on a global market, connecting production and consumption. It is based on delivering products quickly and safely to the final customer, reducing waste in the entire chain. The principles of lean and agile supply chains were deeply analysed in the past by Christopher, van Hoek et al., Towil and others [12, 13, 14]. According to these studies, modern logistics removed the boundaries between producers, their customers and suppliers, in order to create added value. Such an approach requires new operational processes and poses higher levels to organizational structures in the logistics sector. Organizations utilising lean logistics concept are able to adapt their own production processes more efficiently, obtaining better customer value by supporting faster supply and with better predictability of customer's requests. Consequently, such a lean supply chain leads to a superior financial performance for all organizations in the supply chain.

During the last decade lean logistics has evolved firstly from just-in-time manufacturing to lean manufacturing, and secondly from a supply chain to a lean and agile supply chain. Wang et al. emphasize that manufacturing focus evolved when organizations analyzed all components in the production process and ways of achieving higher added value. Interactions between different components always produce additional waste; therefore, it is certainly present in intermodal transport. In addition, modern logistics is based on intermodality, and therefore, different operators, such as transporters and carriers are used successively. All these subjects must be efficient in information flow, fast handling, documentation and transportation. Everyone in the chain must be aligned with each other's needs and must accept others as important players in providing efficient logistics. It is clear that a single subject in the supply chain cannot eliminate waste in the entire chain, but it can reduce waste significantly with an efficient network and information flow. Therefore, a single door-to-door provider easily achieves lower costs, higher quality standards and lower lead time.

\subsection{Agile port services and inland transport operations}

New trends in the supply chain management have many direct impacts on the shipping industry. Shipping 
lines, terminal operators, shipping agents and forwarders must perform a range of different operations in order to satisfy the increasing customers' needs. Lean logistics is in direct connection with a reliable ocean service and an agile port service. Moreover, it is based on flexible inland transportation, in-time documentation and fluent information flow. Thus, all players in the shipping industry must provide agile intermodal transport services. All operational requirements must be managed with special care, otherwise they may inflict heavy cost elements and depress the lean supply chain concept.

Lean logistics concept imposes various new processes on shipping subjects. Firstly, they must provide and control the shipment from door-to-door or from supplier to the final consignee. Consequently, they must also provide an adequate inland service and warehouse operations. These two operations are very important in logistics chains and may cause, with improper management, higher costs of the entire chain, even with excellent sea transportation which they offer as their core business. In addition, even port and terminal operators must eliminate the non-value added activities, by reducing waste operations and consequently, extra costs in the entire logistics process. They should have highly automated and flexible manipulating equipment and operating IT programs, in order to economically switch from one operation to another [6]. According to Liu et al. the element support of agile service in port enterprises are: agile techniques, agile organizations and agile port management [15]. Thus ports and inland intermodal terminals should keep focus on these important elements.

\section{CHANGES IN CONTAINER TRANSPORT ORGANIZATION}

\subsection{Difficulties of traditional supply chain model}

The global container industry experienced a period of extreme growth during the last decade. Logistics sector followed this step. It is still in the period of strong development, despite the actual fall of container transport. Nevertheless, the global market is suffering from the global financial and economic crisis; therefore, the logistics sector is forced to find new possibilities of managing time, space and information between global manufacturing and consumption points. The shippers require and will require logistics operators' services that are even more specialized in door-to-door delivery and the shortest transit times. The main aim remains cost efficiency.

Consequently, the traditional supply chain organization with seven players working in one logistics chain is under great pressure (Figure 1). The main focus is on reducing logistics subjects, such as forwarders and shipping agents, in the existing organizational structure of logistics chains. This has important and deep impact on the shipping sector with direct relation to port services. The traditional role of port forwarders and shipping agents may disappear, and consequently, shipping companies may enter the logistics market as new supply chain players.

A new approach of the 4PL and even the 5PL logistics concept is going to additionally break the traditional supply chain. These solutions focus on providing overall logistics for the entire supply chain. In addition, such supply chain management integrates all activities associated with the cargo flow in the respective logistics networks through improved supply chain relationships based on a common performance measurement framework for attaining close, collaborative and well-coordinated network relationships to achieve a competitive edge [1]. Port forwarders and shipping agents are not part of these new logistics concepts, as their logistics services are treated as potential logistics waste.

\subsection{Shipping Line's logistics service}

With the expansion of the global supply chains, the carriers, which have developed complex logistics services, are lifting the competition platform from the low-level price competition to the competition of controlling the entire logistics chain. However, they are still facing high pressure to lower their costs on the

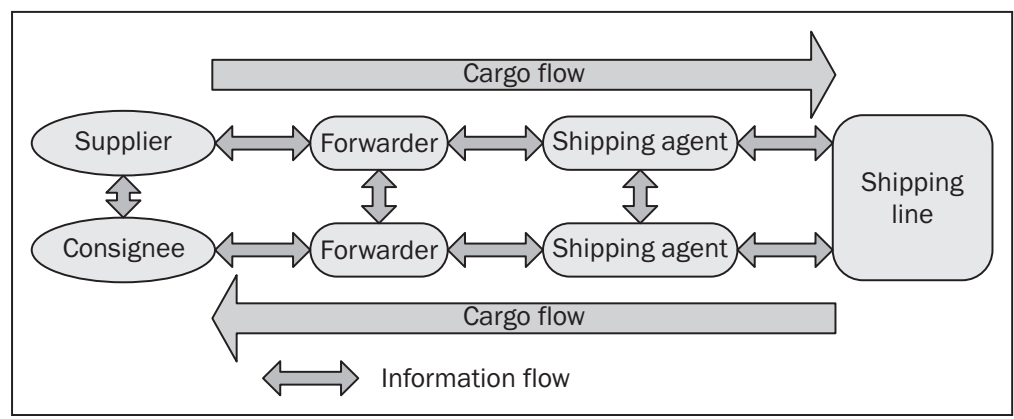

Figure 1 - Logistics subjects and their relation in traditional supply chain 


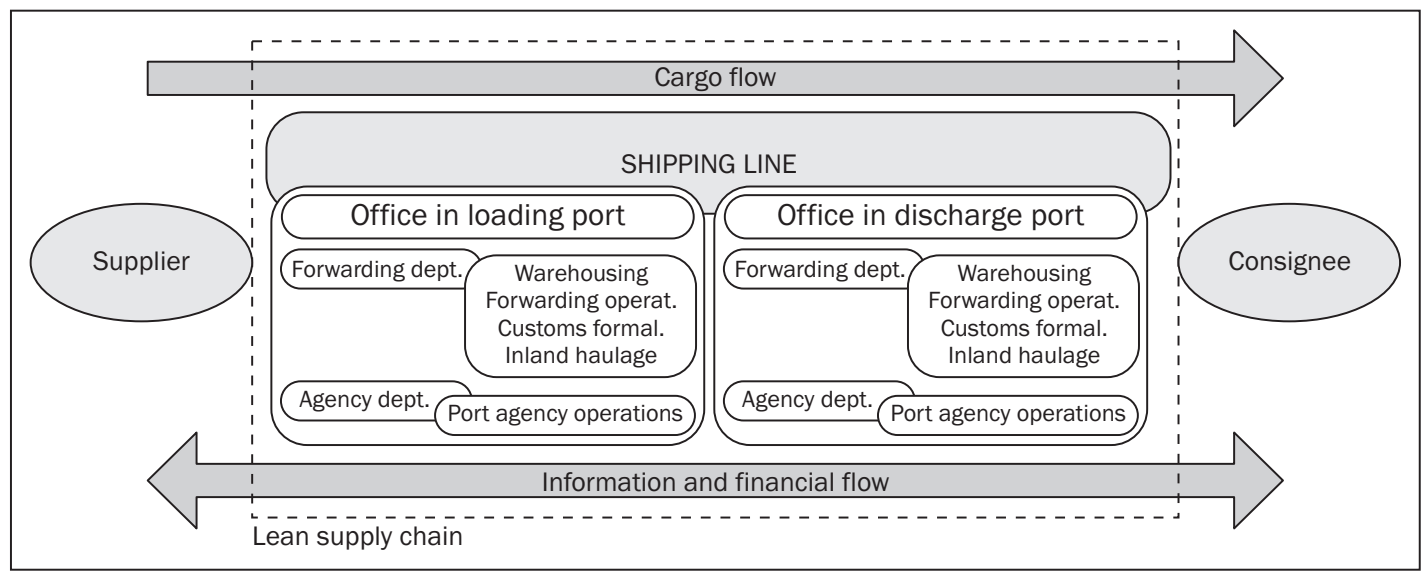

Figure 2 - Model of organizational structure of global shipping line

entire transport journey [16]. In order to provide cost efficiency and reliable door services, shipping lines are massively establishing their own port offices and offices at the most important logistics centres across the world.

Shipping lines can offer lean logistics chains as they have the ability to discount rates to global logistics enterprises via special rates, ensuring annual contracts on different global shipping tenders. At the same time, they can give additional slots of space to the main transport routes, securing a reliable transport service and transit time. Line's can benefit from the economy of scale because they are sure of their income in advance.

Shipping lines are in a position to put pressure on port operators to obtain agile port services; even port and terminal operators are trying to capture value and revenue. Where possible and desired, port or terminal operators are teaming up with shippers and logistics providers to create value through developing concepts and to streamline and synchronize the supply chains [9]. They try to offer agile services to the market, in order to attract new cargo and new clients or to steal them from the neighbouring port systems. Consequently, shipping lines can secure and benefit from lower port costs for port manipulations and services, because they control and can secure new massive container volumes.

In addition, shipping lines can obtain priorities in cargo dispatch from ports, especially by rail. This is because of the obvious economies of scale, as they control huge quantities of containerised cargo. As such they offer shorter total transit time in the door-to-door logistics concept. With special agreements with rail operators they can agree on special timetables, on the priorities within the entire transport route and on lower rail transport costs. Moreover, they are in a position to leave any empty intermodal equipment containers at inland intermodal terminal and thus additionally lower inland transport costs.

\subsection{The analysis of Line's lean supply chain model}

As described, the traditional supply chain consists of at least seven subjects, such as the supplier, the supplier's forwarder, the shipping agent at port of loading, the shipping line, the shipping agent at port of discharge, the consignee and the consignee's forwarder. In the modern lean supply and in the 4PL chain concept only three subjects can be present. These are the supplier, the consignee and just one logistics provider - the shipping line. Port operators are important subjects in the logistics chain, but they are selling their services just to the shipping lines. The paradox of container transport is even higher, as shipping lines are entering the sphere of maritime or inland terminal operator. As such they control the entire door-to-door supply chain.

In big economy basins, a shipping line acts as a forwarder and as a shipping agent. They can easily secure such an organization through their own offices which act on the market as specialized logistics providers. This kind of logistics service provides forwarding operations and pure agent operations in the ports. Such an organization requires a specialized organizational structure in a local office at the supplier's and consignee's points, and, in a broader context of an entire shipping line.

The model in Figure 2 represents an organizational structure of a global shipping line. Such an organization must offer all services as competitive individual logistics subjects do. They must assure:

- core carrier programs and customers' programmes or communication interfaces,

- improved transportation administrative processes and automated functions,

- right-sizing equipment for door-to-door delivery,

- cross-docking,

- import and export transportation processes, such as customs, veterinary and other inspections, etc.,

- inland delivery, combining different transport modes. 
Moreover, shipping lines with the previously described organization are very often more effective in time and costs compared to traditional forwarders and shipping agents. They reduce all waste in the logistics chain and offer fluent information and financial flow, not only in their specific areas of operation, but also in the broader logistics context. This is especially true now with the constant development of new technologies and working practices and with fully trained staff. Presently, IT and commercial knowledge is essential for obtaining new businesses and for further developing of the company's structure, but "lean" also means to constantly improve all services and monitor clients' satisfaction.

\section{ANALYSIS IN CASE OF INTERMODAL SERVICE THROUGH PORT OF KOPER}

With the analysis, which was carried out in Slovenia, we tried to practically analyse the lean supply chain model for cargo in transit through the Port of Koper. We made an analysis of customers' expectations, of actual intermodal services provided by different intermodal operators and an analysis of total costs, where we focused our attention on cargo in arrival from Asia to Central and South-east Europe.

With the analysis we checked the port's willingness to offer agile services and rail operator's willingness to secure reliable and on-time services. Special emphasis was on the shipping lines' lean service model, and whether shipping lines really offer the leanest supply chains in comparison to traditional supply chain model offered by port forwarders and shipping agents.

\subsection{Analysis of customer's expectations}

According to our research, small companies prefer the cost-effective logistics service to reliable supply chain. Moreover, transit time is not so significant and they are prepared to accept up to $20 \%$ higher transit time if the total cost reduction is $7 \%$. On the other hand, we obtained completely contrary results from the big and important companies. Their expectations are mostly focused on a reliable supply chain and shortest total transit time. Results are shown in Figure 3.

It is obvious that the market holds enough space for cost-effective services, which do not provide optimal time service solutions, but there is also space for logistics services which can secure optimal total transit times, but for higher total logistics costs.

With our research we also checked the willingness of customers to give their cargo supply chain into the hands of shipping lines. The main emphasis was to check whether customers have confidence in the lean shipping line concept or whether they are still oriented to the usage of traditional port forwarders to organize

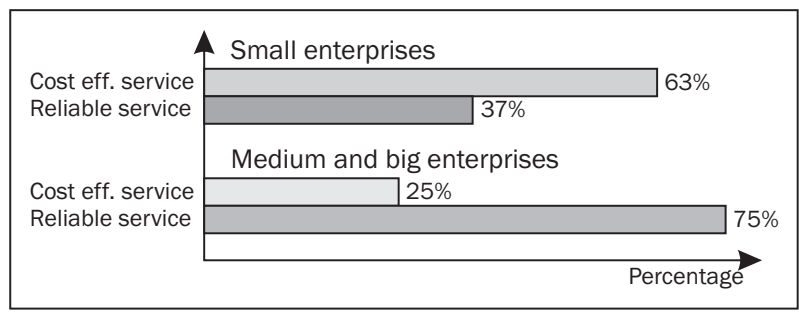

Figure 3 - Small, medium and big enterprise intermodal service expectations

traditional supply chains. We also obtained different results in the matter of organizing the supply chain. Big enterprises are prepared to use the shipping lines, while smaller customers still mostly like and trust their port forwarders.

\subsection{Analysis of intermodal services}

In our research different intermodal services through the Port of Koper were surveyed. We checked the rail services to Central Europe and found out that some shipping lines organize their own frequent block trains up to four times per week. The results, summarized in Table 1, show that the most frequent final destinations are Ljubljana, Maribor, Budapest, Munich, Belgrade and Zagreb. From the aspect of cargo quantity, the Koper-Budapest route is the main rail service route, with over 16 dispatches per week. Consequently, we focused our survey on this important container route. More than half of these block trains are provided by shipping lines. At the same time, different intermodal operators also organize block trains on this transport route, but their departures are not so frequent.

According to our results both shipping lines and intermodal transport operators have more or less the same service, compared to transit time of single block train and service reliability. However, the main difference is in train dispatch, as shipping lines very often obtain direct transfer of containers from ships to rail wagons. The difference is from 2 up to 6 days or even more.

Thus, they save time and at the same time economize port's manipulations. If direct manipulations are not possible, all containers are directly stowed in a special position for immediate dispatch to the first available block train. From the port's perspective, this service provides agile services and cuts additional operational costs.

Local port forwarders and shipping agents use regular intermodal connections. Most often they receive a release for rail dispatch after a few days. In such cases shipping lines request special charges for the demurrage or the container detention.

Finally, we came to the conclusion that shipping lines can secure and offer better port services and better inland intermodal connections on the market. 
Table 1 - Rail transport services with block-trains from Port of Koper

\begin{tabular}{||l|l|l|l||}
\hline \multicolumn{1}{|c|}{ Country } & \multicolumn{1}{c|}{ Route } & \multicolumn{1}{c|}{ Provider } & \multicolumn{1}{c||}{ Frency } \\
\hline \hline Slovenia & Koper-Ljubljana-Maribor & Adriakombi & 5 trains/week \\
\hline Germany & Koper - Ljubljana - München & Adriakombi & 5 trains/week \\
\hline Hungary & Koper-Budapest & Intercontainer & 2 trains/week \\
\hline Hungary & Koper-Budapest & ERS-Maersk & 3 trains/week \\
\hline Hungary & Koper-Budapest & Adriakombi & 2 trains/week \\
\hline Hungary & Koper-Szolnok/Budaors & Navismart & 3 trains/week \\
\hline Hungary & Koper-Torokbalint & Navismart & 3 trains/week \\
\hline Hungary & Koper-Budapest & ARGO & 1 train/week \\
\hline Hungary & Koper-Budapest & Metrans & 2 trains/week \\
\hline Slovakia & Koper-Zilina & Adriakombi & 4 trains/week \\
\hline Slovakia & Koper-Bratislava & Adriakombi & 2 trains/week \\
\hline Slovakia & Koper-Dunajska Streda & Metrans & 3 trains/week \\
\hline Serbia & Koper-Ljubljana-Belgrade & Adriakombi & 5 trains/week \\
\hline Croatia & Koper-Zagreb & Adriakombi & 5 trains/week \\
\hline Austria & Koper-Graz-Koper & Adria Transport & as per demand \\
\hline Austria & Koper-Graz-Koper & Adriakombi & as per demand \\
\hline Romania & Koper-Arad-Koper & Adria Transport & 1 train/week \\
\hline \hline
\end{tabular}

Table 2 - Total costs comparison Far East-Budapest with rail service Koper-Budapest in (EUR)

\begin{tabular}{||l|c|c|c|c|c|c||}
\hline \multirow{4}{*}{$\begin{array}{l}\text { Shipping } \\
\text { line }\end{array}$} & Equipment & Ocean Freight & Port manipulations & Delivery \& Forwarding & Inland transport & Total costs \\
\cline { 2 - 7 } & $20^{\prime} \mathrm{DB}$ & 1,200 & 75 & 0 & 200 & 1,475 \\
\cline { 2 - 7 } & $40^{\prime} \mathrm{DB}$ & 2,100 & 75 & 0 & 300 & 2,475 \\
\hline \hline \multirow{4}{*}{ Forwarder } & $40^{\prime} \mathrm{HC}$ & 2,100 & 75 & 0 & 300 & 2,475 \\
\cline { 2 - 8 } & $20^{\prime} \mathrm{DB}$ & 1,300 & 110 & 70 & 250 & 1,730 \\
\cline { 2 - 8 } & $40^{\prime} \mathrm{DB}$ & 2,250 & 110 & 70 & 400 & 2,830 \\
\cline { 2 - 8 } & $40^{\prime} \mathrm{HC}$ & 2,300 & 110 & 70 & 400 & 2,880 \\
\hline
\end{tabular}

Moreover, they are supported by the port, because such service increases productivity, decreases manipulation and consequently cost, while at the same time makes the port competitive on the global market.

\subsection{Analysis of total cost model}

The third analysis of computed research was focused on the total cost model. We analysed different services for 20' dry box, 40' dry box and 40' high cube container on the main important route from the Far East to Koper with the final destination being Budapest. According to the average result of the survey, the transport of containers in Line's organization is cheaper than transport of container organized by forwarders. The average costs on the main routes from the Far East to Budapest are collected in Table 2.

According to total cost analysis, shipping lines offer on the market notably lower tariff. According to our research the difference in one way service is between 17 to $22 \%$ in favour of shipping lines. The results, which included transport of empty container redelivery back to Koper, show that the total difference is even higher. It varies between 18 and $24 \%$ of total transport costs.

Moreover, shipping lines are in a position to leave any empty equipment in Budapest and thus not charge the empty return transport back to Koper. On the other hand, in most cases forwarders are forced to redeliver empty containers to Koper and the difference in total costs is additional EUR250 for 20' and EUR400 for 40' container. In addition, port forwarders are limited with detention free time, where extra costs can occur, if they do not redeliver containers within the agreed time. It is obvious that traditional port forwarders and shipping agents hardly compete with the Line's service.

\section{AGILE PORT AND INTERMODAL TRANSPORT OPERATIONS MODEL}

According to our research, shipping lines are in position to organize lean supply chains for contain- 


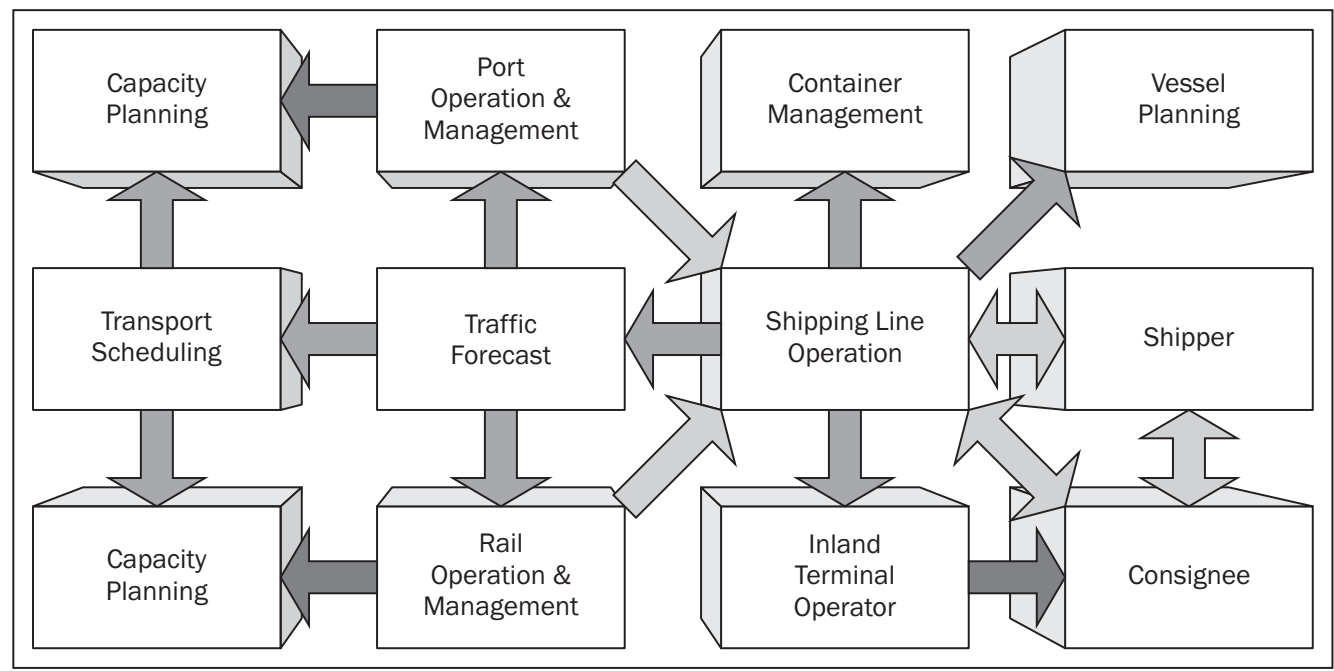

Figure 4 - Agile port and intermodal transport operations model

erized cargo. They are in a position to influence the port's performance through massive cargo flow and scheduled port operations. Moreover, they can press the port operators to extend operating hours and to organize agile operations. On the other side they have the power to press rail operators for agile inland service, which in most cases results also in cost savings. Especially in the railway services massive cargo flows can reduce the total inland rates. Shipping lines capitalize this effectively, which has been confirmed by the research performed in the case of intermodal service through the port of Koper.

Based on the established facts we worked out that the agile port and the intermodal transport operations model are suitable for improving the intermodal service and for securing lean supply chains for containerized cargo (Figure 4). The shipping line is a unique logistics subject in direct connection with a shipper on one side and a consignee on the other. All other intermodal operators in the supply chain communicate only through one logistics channel, which is under the control of the shipping line. Moreover, traffic forecast and ocean transport scheduling help port and rail operators with adequate planning capacities at their side and with organizing their operation processes accordingly. It can be anticipated that traditional shipping agents and port forwarders are not in a position to organize such logistics process in the ports and in hinterland connections.

Proposed agile port and intermodal transport operations model can be adopted in every port and maritime container terminal. It can also be the base of IT models and tools development to support intermodal operations in the ports or specialized maritime container terminals. The main focus is on the agile model and on reducing the number of involved subjects. Consequently, the communication should be established in this way, in order to eliminate waste information flows and additional time. IT tools should be worked out for such information exchange. Moreover, customs authorities and inspection companies should be involved adequately, in order to organize agile services in the ports, on the borders between different countries and at final destinations. Consequently, time and cost reduction on the entire intermodal transport route should be achieved and lean/agile supply chains likewise.

\section{CONCLUSION}

Introduction of supply chain management concept was one of the main steps in logistics evolution, but with the last global crisis, the lean supply chain concept raised the platform on a higher level. Trends in modern logistics inevitably show that in the future a reduced number of logistics subjects will be involved in supply chain management. Complete logistics providers are forced to move commodities from door to door and even more on the just-in-time principle. Some global shipping lines have already realized that they must offer the lean supply chain concept on the global market. They are forced to remove waste on the entire logistics chain; therefore, they must develop and adopt efficient agile intermodal models. Consequently, they reduce logistics players in the supply chain of containerized cargo and put pressure on ports and inland transport operators, especially on rail operators.

The obtained results clearly show that shipping lines can secure and offer better port services and better inland intermodal connections on the market. Moreover, they are supported by the port and inland transport operators as they control massive cargo flows and can secure scheduled port operations and regular inland transport departures. Consequently, they are in a position to organize lean supply chains for containerized cargo. 
Based on the established facts we came to the conclusion that the agile port and the intermodal transport operations model are suitable for improving the intermodal service and for securing the lean supply chains for containerized cargo. The model presented in the article introduces a new prospect for the operational and information flow. Traditional players, such as port forwarders and shipping agents are not necessary in this new kind of organization. Shipping lines can eliminate waste operations and communications, reflecting in shorter the total transit time and in total transport cost reduction.

Further studies should overcome these findings and the proposed model. Consequently, efficient IT tools should be worked out for such an information exchange, in order to speed up the cargo movement on the entire logistics chain and make the information exchange between logistics subjects more efficient.

\section{Dr. BOJAN BEŠKOVNIK}

E-mail: bojan.beskovnik@intereuropa.si

Intereuropa, Globalni logistični servis, d.d.

Vojkovo nabrežje 32, 6000 Koper, Slovenija

Dr. ELEN TWRDY

E-mail: elen.twrdy@fpp.uni-lj.si

Univerza v Ljubljani, Fakulteta za pomorstvo in promet

Pot pomorščakov 4, 6320 Portorož, Slovenija

\section{POVZETEK}

Članek opisuje strateški pogled pričakovanj gospodarstva od koncepta vitkih oskrbovalnih verig v zvezi s kontejnersko pomorsko industrijo. Globalni trg vrši močan pritisk na ladjarsko industrijo, ker novi trendi $v$ logistiki iščejo nove priložnosti, da bi odrezali nepotrebne stroške in igralce $v$ upravljanju oskrbovalne verige in $v$ intermodalnem transportu. Zaradi tega smo opravili raziskavo, kako lahko intermodalni transport zagotovi učinkovite transportne operacije. Poudarek je zlasti na postavitvi agilnega pristaniškega in intermodalnega transportnega modela, $v$ katerem bi bili vsi potrebni subjekti vključeni v skupno oskrbovalno verigo. Tako smo analizirali pristaniške operaterje, ladjarje in kopenske transportne operaterje ter kako iz vsakdanjih operativnih postopkov izločajo nepotrebne procese. Upoštevajoč $v s a$ pomembna dinamična dejstva $v$ kontejnerski in ladjarski industriji ter naših analiz intermodalnih servisov preko pristanišča Koper, predlagamo agilni model pristaniških in kopenskih operacij, ki je primeren za izboljšanje intermodalnega servisa in za zagotovitev vitkih oskrbovalnih verig kontejneriziranega tovora. Posledično smo prišli do ugotovitve, da nekateri tradicionalni subjekti $v$ tradicionalnih oskrbovalnih verigah niso potrebni, medtem ko naj bi bili drugi, kot na primer carina in inšpekcijski organi, vključeni na primeren način, da zagotovijo učinkovito organizacijo agilnih servisov v pristaniščih, na mejah med različnimi državami in na končnih destinacijah.

\section{KLUUČNE BESEDE}

vitke oskrbovalne verige, agilne intermodalne operacije, ladjarji, pristaniški operaterji, kopenski transportni operaterji

\section{LITERATURE}

[1] Vasiliauskas, A. V., Jakubauskas, G.: Principle and benefits of third party logistics approach when managing logistics supply chain, TRANSPORT, Vol. 22, No. 2, 2007, pp. 68-72

[2] Wang. G., Huang, S. H., Dismukes, J. P.: Product-driven supply chain selection using integrated multi-criteria decision-making methodology, International Journal of Production Economies, No. 91, 2004, pp. 1-15

[3] Steenken, D., Voss, S., Stahlbock, R.: Container Terminal Operation and Operation Research - a Classification and Literature Review, OR Spectrum, No. 26, 2004, pp 3-49

[4] Vis, I.F.A.; De Koster, R.: Transvesselment of Containers at a Container Terminal: an Overview, European Journal of Operational Research, Vol. 147, No. 1, 2003, pp. 1-16

[5] Notteboom, T.E., Rodrigue J.P.: Port Regionalization: Towards a New Phase in Port Development, Maritime Policy and Management, Vol. 32, No. 3, 2005, pp. 297 313

[6] Paixao, A. C., Marlow, P. B.: Fourth generation ports - a question on an agility?, International Journal of Physical Distribution and Logistics Management, Vol. 33, No. 4, 2003, pp. 335-376

[7] Van Klink, H. A., Van den Berg, G.: Gateways and Intermodalism, Journal of Transport Geography, Vol. 6, No. 1, 1998, pp. 1-9

[8] McCalla, R. J.: Global Change, Local Pain: Intermodal Seaport Terminals and Their Service Areas, Journal of Transport Geography. Vol. 7, No. 2, 1999, pp. 247-254

[9] Rodrigue, J. P., Notteboom, T.: The Terminalization of Supply Chains: Reassessing the Role of Terminals in Port/Hinterland Logistics Relations, Maritime Policy and Management, 26(2), 2009, pp. 165-183

[10] Foster, T. A.: Ports: What Shippers Should Look For. Distribution Worldwide, 1978, pp. 32-36

[11] Ng, K.Y.: Assessing the Attractiveness of the Ports in the North European Container Transhipment market, Maritime Economics and Logistics, Vol. 3, 2006, pp. 234-241

[12] Christopher, M.: The Agile Supply Chain: Competing in Volatile Markets, Industrial Marketing Management, Vol. 29, No. 1, 2000, pp. 37-44

[13] Van Hoek, R. I., Harrison, A., Christopher, M.: Measuring agile capabilities in the supply chain, International Journal of Operations \& Production Research, Vol. 21, No. 2, 2001, pp. 126-148

[14] Towil, D., Christopher, M.: The Supply Chain Strategy Conundrum: To Be Lean Or Agile Or To Be Lean And Agile, Supply chain practice, Vol. 5, No. 2, 2003, pp. 30-45

[15] Liu, W., Xu, H., Zhao. X.: Agile Service Oriented Shipping Companies in the Container Terminal, TRANSPORT, Vol. 24, No. 2, 2009, pp. 143-153

[16] United Nations Economic and Social Commission for Asia and Pacific (UNESCAP), Changes in International Container Shipping and Port Environment, New York, U.S.A., 2005 